\title{
Supplementing the lack of ubuntu? The ministry of Zimbabwe's Mashoko Christian Hospital to people living with HIV and AIDS in challenging their stigmatisation in the church
}

\begin{tabular}{|c|c|}
\hline \multicolumn{2}{|c|}{$\begin{array}{l}\text { Authors: } \\
\text { Collium Banda } 10 \\
\text { Suspicion Mudzanire }{ }^{2}\end{array}$} \\
\hline \multicolumn{2}{|c|}{$\begin{array}{l}\text { Affiliations: } \\
{ }^{1} \text { Unit for Reformational } \\
\text { Theology and the } \\
\text { Development of the } \\
\text { South African Society, Faculty } \\
\text { of Theology, North-West } \\
\text { University, Vanderbijlpark, } \\
\text { South Africa }\end{array}$} \\
\hline \multicolumn{2}{|c|}{$\begin{array}{l}{ }^{2} \text { Faculty of Theology, } \\
\text { Stellenbosch University, } \\
\text { Stellenbosch, South Africa }\end{array}$} \\
\hline \multicolumn{2}{|c|}{$\begin{array}{l}\text { Corresponding author: } \\
\text { Collium Banda, } \\
\text { collium@gmail.com }\end{array}$} \\
\hline \multicolumn{2}{|c|}{$\begin{array}{l}\text { Dates: } \\
\text { Received: } 18 \text { Mar. } 2019 \\
\text { Accepted: } 26 \text { June } 2019 \\
\text { Published: } 30 \text { Sept. } 2019\end{array}$} \\
\hline \multicolumn{2}{|c|}{$\begin{array}{l}\text { How to cite this article: } \\
\text { Banda, C. \& Mudzanire, S., } \\
\text { 2019, 'Supplementing the } \\
\text { lack of ubuntu? The ministry } \\
\text { of Zimbabwe's Mashoko } \\
\text { Christian Hospital to people } \\
\text { living with HIV and AIDS in } \\
\text { challenging their } \\
\text { stigmatisation in the church', } \\
\text { HTS Teologiese Studies/ } \\
\text { Theological Studies } 75(4), \\
\text { a5468. https://doi.org/ } \\
\text { 10.4102/hts.v75i4.5468 }\end{array}$} \\
\hline \multicolumn{2}{|c|}{$\begin{array}{l}\text { Copyright: } \\
\text { (c) 2019. The Authors. } \\
\text { Licensee: AOSIS. This work } \\
\text { is licensed under the } \\
\text { Creative Commons } \\
\text { Attribution License. }\end{array}$} \\
\hline Read online: & \\
\hline 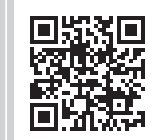 & $\begin{array}{l}\text { Scan this QR } \\
\text { code with your } \\
\text { smart phone or } \\
\text { mobile device } \\
\text { to read online. }\end{array}$ \\
\hline
\end{tabular}

This article uses the African communal concept of ubuntu to reflect on the ministry of Mashoko Christian Hospital $(\mathrm{MCH})$, Zimbabwe, to people living with the human immunodeficiency virus (HIV) and AIDS (PLWHA) during the early days since the discovery of the disease. The main question this article seeks to answer is: from a perspective of the African philosophy of ubuntu, how did the ministry of MCH to PLWHA challenge the fear and judgemental attitudes towards the disease within the Churches of Christ in Zimbabwe? This leads to another question: what should the churches learn from $\mathrm{MCH}$ 's response to HIV and AIDS? This article only focusses on trends in conduct and not on a detailed history of engaging HIV and AIDS. The significance of this article is to demonstrate the important role played by faith-based organisations (FBOs) in complementing the compassion and care often lacking in the official churches' response to HIV and AIDS.

Keywords: Ubuntu; HIV and AIDS; Mashoko Christian Hospital; Church and HIV/AIDS; Churches of Christ in Zimbabwe; Medical missions.

\section{Introduction and background}

Ubuntu is a cherished ethical concept in many traditional African contexts that emphasises communal aspects such as hospitality, care, solidarity and interdependence. This article uses this cherished foundational African communal concept to critically reflect on the gap filled by faithbased organisations (FBOs) in Africa by supporting people living with human immunodeficiency virus (HIV) and AIDS (PLWHA) since the early days of the discovery of HIV when churches stigmatised and discriminated against them.

Mashoko Christian Hospital (MCH), located in a remote rural area of Masvingo province, Zimbabwe, is used as an example of an FBO that demonstrated ubuntu care ethics towards PLWHA and challenged the church's lack of compassion towards the affected people. In the early days, churches were often judgemental and discriminatory, portraying the virus as a punishment for sexually immoral people (Haddad 2005:32).

Consequently, many churches did not prepare themselves to respond meaningfully to the problem of HIV and AIDS until the disease had taken a heavy toll on many people (Haddad 2005:30, 33). It was the FBOs acting on the fringes of churches that led the initiatives for compassion and nondiscrimination to PLWHA (Marshall \& Taylor 2006; Morgan, Green \& Boesten 2014).

Faith-based organisations are difficult to define succinctly because they exist in various forms and shapes (Van der Merwe, Swart \& Hendriks 2009:125-128; Pallant 2012:2; Sider \& Unruh 2004). ${ }^{1}$ This article understands FBOs as (but not exclusively) organisations whose mission is motivated, shaped or based on religious or spiritual beliefs.

Various scholars have proposed different types of FBOs, such as Sider's typology (cited in James 2009:13) of faith-permeated, faith-centred, faith-affiliated, faith-background and faith-secular partnerships and Clarke's typology of FBOs (cited in James 2009:13) where faith functions 1.See James (2009) for a useful discussion on the nature and attributes of FBOs.

Note: Faith-Based Organisations, sub-edited by Nadine Bouwers du Toit (Stellenbosch University), Vhumani Magezi (North-West University) and Elisabet le Roux (Stellenbosch University). 
passively, actively, persuasively or exclusively. This article projects $\mathrm{MCH}$ as an FBO that is part of the greater Mashoko Christian Mission station, because it is a medical institution that emerged and continues to exist with a Christian interest to provide medical care for rural people, most of whom are poor. The hospital exists and runs as a medical facility under the Churches of Christ in Zimbabwe, with a medical mission permeated and centred on Christian faith (Grubbs 1996:21). Mashoko Christian Hospital administrators such as the current resident doctor, Zindoga Bungu (2013:13), see their medical work as ultimately contributing to the accomplishment of the Great Commission. This means that 'medical care is used as a method of evangelism to bring individuals and communities to believe in Christ' (Magezi 2012:7). This opens $\mathrm{MCH}$ to criticism of blurring the line between providing medical care and proselytising people using the same resources (Magezi 2018:6). The hospital sees itself as a ministry of the church but administrated through corporate business principles used in the secular world. There is also a duality of accountability to the church as a ministry of the church and also to the state that oversees and regulates all medical facilities and practices in the country. MCH fits into Magezi's (2012:5) notion of 'government clad in church health care' because it is essentially run by government with the Ministry of Health controlling its work.

The article critically reflects on how MCH's ministry to PLWHA challenged the mainstream or formal church's discrimination and stigmatisation of people with the disease and provided what the formal church ought to have provided but failed. Indeed, $\mathrm{MCH}$, as part of a mission station, can be classified as 'church'. However, in this article, FBOs are treated as an informal church and the mainstream church as the formal church. By formal or mainstream church, we mean the area of the spiritual ministration of the church that includes evangelism and the administration of the sacraments which is often thought by many Christians to be the primary ministry of the officially appointed ministers and lay leaders. Oduyoye (1997:72-75) uses the idea of 'informal church' to refer to the parallel associations, societies and fellowships formed by women in established churches, which they find to be more supportive and caring to them than the ministration provided by the officially appointed ministers and lay leaders in the established structures. Similarly, it can be said that in time of great crisis, PLWHA relied on informal church (FBOs) because the formal church discriminated against them.

Consequently, the main question of the article is: From a perspective of the African philosophy of ubuntu, how did the early ministry of $\mathrm{MCH}$ to PLWHA challenge the fear and judgemental attitudes towards the disease within the Churches of Christ in Zimbabwe? This leads to a further question: What should churches learn from the hospital's response to HIV and AIDS? This article only focusses on trends in conduct within Churches of Christ in Zimbabwe as specifically reflected by $\mathrm{MCH}$, and not on a detailed history of engaging HIV and AIDS (Mbona 2013), nor does it take any interest to describe the model of church-driven medical interventions (Magezi 2012, 2018).
Methodologically, the article draws from the written personal testimonies of medical missionaries who ran the $\mathrm{MCH}$ when the HIV pandemic erupted, and also uses a broad range of scholarship on ubuntu and on church and HIV and AIDS. In addition to showing the important role of FBOs in completing the compassionate care that lacked in churches towards PLWHA in the early days of the discovery of the disease, this article also attempts to fill the gap of the absence of scholarly reflection on both the ministry of $\mathrm{MCH}$ and church involvement in HIV and AIDS issues in the Churches of Christ in Zimbabwe.

\section{The notion of ubuntu and the context of HIV and AIDS in Africa}

The emergence of HIV and AIDS shook the African belief in ubuntu by testing the very communal nature of African societies. Ubuntu, which is also called unhu or hunhu in Shona, expresses the Nguni saying, umuntu ngumuntu ngabantu, which can be loosely translated in English as 'one is a person through other people'.

Ubuntu is 'a distinctive African quality that values collective good, humanness and respect for the community' (Magezi 2017:112). It is a foundational ethic of interconnected and supportive communal relations in many African communities. $^{2}$

Ubuntu is difficult to define succinctly. Archbishop Emeritus Desmond Tutu (2009) states:

Ubuntu is very difficult to render into a Western language. It speaks to the very essence of being human. When we want to give high praise to someone we say, 'Yu, u nobuntu'; 'Hey, he or she has ubuntu'. This means they are generous, hospitable, friendly, caring, and compassionate. They share what they have. (p. 34)

In agreement with this understanding, Letseka (2012:51) shows South African Retired Justice Yvonne Mokgoro, also affirming difficulties in defining ubuntu in Western languages. Nonetheless, Tutu shows that at the core of ubuntu is an ethic of care, which encompasses compassion, hospitality and embracing others.

To Chisale $(2018: 1,3)$, ubuntu is 'synonymous with care ethics' that functions as a principle of pastoral care.

According to Chitando (2015:275), 'Ubuntu is an African approach to reality that places emphasis on the community and taking responsibility for each other's burdens'. Several Africans scholars (Chisale 2018:4; Gathogo 2007:112; Letseka 2013:355; Manyonganise 2015:1; Van Norren 2014:256) project ubuntu as expressing Mbiti's (1990:106) famous statement, 'I am, because we are; and since we are, therefore I am'.

2.Gade (2011:313) and Mboti (2015:126) argue that the linking of ubuntu to the proverb umuntu ngumuntu ngabantu is a recent development that began in South Africa between 1993 and 1995. Before this time, according to Gade (2011:313), ubuntu appeared in literature as a human quality, African humanism, a philosophy, ubuntu appeared in literature
an ethic and as a worldview. 
Consequently, as projected by Tutu (2009):

Ubuntu ... means my humanity is caught up, is inextricably bound up, in theirs. We belong in a bundle of life. We say, 'a person is a person through other people'. It is not 'I think therefore I am'. It says rather: 'I am human because I belong'. I participate, I share. A person with Ubuntu is open and available to others, affirming of others, does not feel threatened that others are able and good; for he or she has the proper self-assurance that comes from knowing that he or she belongs in a greater whole, and is diminished when others are humiliated or diminished, when others are tortured or oppressed, or treated as if they were less than who they are. (pp. 34-35)

In this regard, ubuntu means communality, commonality, mutuality and interdependence. The essence of Tutu's statement is captured by Chisale's (2018:4) statement, 'because I am ontologically connected to other people therefore I am obligated to care for their well-being'. Ubuntu upholds the human dignity and value of other people.

Ubuntu is also a moral concept meaning the ethical virtue of a person who can be described as authentically human or one exhibiting true human behaviour that distinguishes one from an animal. Thus, ubuntu expresses personhood or humanness (Masango 2006:931; Meiring 2015:1). Manyonganise (2015:1) explains that among the Shona, it is possible to describe a person as being not a person on the basis of exhibiting negative behaviour.

The aspect of ubuntu that is of interest to this article is the one expressed by Tutu that includes compassionate care, hospitality and humanness towards people inflicted with sickness, such as PLWHA. In this case, ubuntu is a practical philosophy 'marked by responsiveness' (Chisale 2018:4) to crisis situations faced by other people that threaten their existence and human dignity. Ubuntu is accompanied by mercy, compassion, hospitality and generosity (Chisale 2018:6-8). The togetherness, unity and interconnectedness of people in society involve compassionate care for the sick and the suffering.

However, the call for ubuntu ethic of compassion is alert to the concerns raised by feminist theologians that ubuntu is embedded in masculinity and patriarchy that favour the oppression of women by men. That is, its masculine and patriarchal linings make ubuntu exclusionary and discriminatory against women (Manyonganise 2015:3-4). Some African male theologians such as Chitando (2015:69) concur by pointing out that while ubuntu is a valuable ethical resource for addressing contemporary challenges, it is riddled with patriarchal and oppressive elements that seriously disadvantage women. This article takes seriously the exclusionary and discriminatory aspects of ubuntu against women, and calls for ubuntu to be 'de-patriarchalised' (Chitando 2015:280) in order to affirm gender equality.

Furthermore, the appeal to ubuntu is cautious of some ubuntu-based cultural practices that have fuelled the spread of HIV and worked against medically informed practices of arresting new infections. Cultural practices that fuelled the spread of HIV include polygamy, inheriting of the wife of a deceased male relative and the giving of young women to replace deceased married female relatives (e.g. a younger sister given to replace her late older sister), the practice of having a male relative sleep with the wife of an infertile man to give him children and the practice of bringing a young female relative to bear children for a wife who is infertile. These male-oriented marriage practices were often done without HIV testing and counselling for all the parties involved and sometimes they are done while being fully aware that a certain late spouse had died of AIDS-related illness. These are some of the patriarchal practices that promoted the spread of HIV and AIDS among Africans.

Furthermore, because ubuntu values direct human touch, it tended to suppress alertness to the necessity of taking essential precautionary measures in risky situations involving blood spills, resulting in some caregivers being 'also infected as they ignorantly practice mercy and compassion to their beloved relatives' (Magezi \& Louw 2006:70). Notwithstanding the noted concerns, in a context of HIV and AIDS in Africa, ubuntu stands against the discrimination and stigmatisation of PLWHA by calling for acceptance and compassionate care for the people living with the virus.

In its early days, the incurable nature of HIV and AIDS and their devastating effect on victims invoked fear, confusion and helplessness in everyone - including the church. Hoffman (1996:7) explains that the physical aspects of the HIV and AIDS often lead to the first awareness that something is amiss; then they become markers of the relentless progression of the disease'. In the early period following the discovery of the virus, before the development and introduction of antiretroviral (ARV) drugs, the incurable nature of the disease reigned supreme, with very little efficient medical interventions affordable to ordinary people. Therefore, witnessing independent, healthy, strong, elegant and energetic people waste away and become bedridden invalids under the strain of crippling opportunistic infections such as tuberculosis instilled a hopeless terror of HIV and AIDS in many people. However, the challenge faced by the church in an ubuntu professing context was the need to realise that people struggling with HIV and AIDS were still human beings created in God's image and therefore still deserved to be viewed and treated with full human dignity (Mhlanga 2016:1). Ubuntu called for compassionate care and not judgement and stigma. Sadly, there are many PLWHA who died lonely deaths abandoned, ridiculed, feared and their feeble bodies were ravaged by opportunistic infections viewed with shame and disgust.

\section{The church's early problematic response to HIV and AIDS and the challenge of ubuntu}

Bosch's (2011:28) description of Jesus' mission as 'one of dissolving alienation and breaking down all walls of hostility, 
of crossing boundaries between individuals and groups' calls the church to be a community that compassionately embraces diseased people and not to discriminate and destigmatise them. This can be expressed by the ubuntu notion of common good, hospitality, togetherness and compassionate embrace of the excluded people.

When it comes to HIV and AIDS, the church has always been found wanting, and in some cases even promoted the exclusion and stigmatisation of the PWLHA. The serious problem is that the churches often failed to realise that 'HIV is indeed a ministerial and an ecclesiological problem' (Magezi \& Louw 2006:66). There are harrowing tales of churches preaching HIV and AIDS as a punishment or a curse from God for sexually immoral people and public healing sessions that made a spectacle of PWLHA (Haddad 2005:32; Togarasei 2010:432). This does not deny or minimise the fact that HIV and AIDS in Africa are mostly spread through sexual transmission and have strong associations with risky sexual behaviours and multiple sexual partnerships. Nor is it an attempt to minimise the importance of observing God's standards of sexual morality in fighting HIV infections. Rather, this article bemoans the church's lack of ubuntu compassionate care, which leaves many Christian PWLHA relying on organisations outside the formal church for assistance and sustenance (Haddad 2005:33). The impression is then created that HIV and AIDS are not an important subject for the formal church (unless it is being condemned) but is a peripheral subject for FBOs, nongovernment organisations (NGOs) and national governments outside the church.

Ubuntu ethics of care challenges the churches to prioritise life-threatening diseases such as HIV and AIDS because they not only harm people but also lead to their marginalisation. It can be noted that in the gospels Jesus did not make addressing the suffering and pain of people a peripheral activity but a core of his messianic ministry.

While the overall churches' perceptions and attitudes towards HIV and AIDS have significantly improved in recent times, their initial response was extremely negative. The church condemned and stigmatised PLWHA as sexually immoral and who had, therefore, contracted the virus as both a punishment for immorality and a death sentence (Haddad 2005:33; Grubbs 2009:3). Pointing to the popular Christian view of HIV as a punishment for sexually immoral people, Grubbs (2009:3) notes that: 'the first pulpit pronouncements were about the "curse that God had sent on the homosexuals"'. The pandemic was defined as 'gayrelated immune-deficiency (GRID) and linked to heroin addicts' (Kelly 2009:16). However, Grubbs (2009:3) notes that people who initially interpreted HIV and AIDS as a punishment from God failed to realise that most people who were affected by HIV were not homosexuals. In Africa, HIV had a greater impact on women and children. In agreement, Mhlanga (2016:2) notes that, 'The church has been reluctant to respond in a compassionate way since
HIV/AIDS was discovered in the mid-1980s'. He further adds (Mhlanga 2016):

The stigmatization of people with HIV/AIDS was strongly felt in the Zimbabwean churches at its early discovery. It was regarded as the worst disease ever discovered. Christians justified themselves in discriminating against HIV/AIDS victims. The church scorned the victims and believed it was God's punishment on immoral people. Some churches even excommunicated HIV / AIDS positive people from membership, claiming that they had brought shame and embarrassment to the church. (p. 2)

In concurrence, Dr Zindoga Bungu, a resident doctor at $\mathrm{MCH}$, stated in an interview on 09 June 2019 that in the Churches of Christ in Zimbabwe, HIV and AIDS were associated with promiscuity and immoral life, leading to high levels of discrimination against PLWHA. Dr Bungu added that it took time for some Church leaders to change their perspective and lead the church to a new way of thinking about HIV and AIDS.

A 65-year-old man from Mashoko recalled hearing preachers declaring HIV and AIDS as fulfilment of God's word that he will punish people who disobey his laws with incurable diseases. Therefore, to be infected with the virus was viewed as a punishment from God. When interviewed, another elderly Mashoko villager said AIDS was preached in the church as self-inflicted suffering and was often expressed in the Shona proverb, warumwa nechekuchera [loosely translated as one has been bitten by what he or she dug up on their own, such as a scorpion or snake]. The elder added that people mocked PLWHA as suffering from self-inflicted wounds and disassociated themselves from them. Another elder remembers preachers proclaiming that AIDS was God's means of punishing prostitutes and promiscuous men. These sentiments highlight the intense discrimination and stigmatisation faced by PLWHA. The sentiments also highlight the extent to which HIV and AIDS were feared as a death sentence.

In a time of crisis and desperation, the church failed to demonstrate ubuntu by lacking compassion, care and hospitability towards PLWHA, but rather treated them with condemnation, hostility and outright rejection.

The disease created tensions in relationships among families, churches and in communities as some families 'quarantined and isolated HIV / AIDS victims to their own houses and fed them separately' (Mhlanga 2016:2). This means that the 'stigma of HIV / AIDS was similar to the stigma of lepers in Israel' (Mhlanga 2016:2). The stigmatisation of PLWHA runs across all churches including Pentecostal churches (Machingura 2012:306-308), meaning that all churches are guilty of stigmatising and judging PLWHA.

Machingura's (2012) article shows that among Pentecostals HIV and AIDS are a double sword: to contract the HIV virus is viewed as an evidence of sexual immorality and to suffer from AIDS is viewed as an evidence of lack of faith. 
The idea of taking HIV as a punishment derives from 'Deutronomistic theology' that believes that obedience to God brings blessing and disobedience brings curses (Dt 7:12-15; Togarasei 2010:430). Christians subscribing to this school of thought draw scriptural support from the idea of God inflicting sickness on sinners as a form of punishment which is a prevalent theme in the Old Testament (Togarasei 2010:431). Biblical texts such as Deuteronomy 7:12-15, Luke 21:11 and Mark 5:24-43 are commonly cited when stigmatising HIV and AIDS as a punishment, while texts such as Mark 5:24-43 are commonly used to discourage PLWHA from taking ARV medications but to instead seek miraculous healing (Machingura 2012:314-316).

In summary, stigmatising theological perspectives were the earliest and the most prominent Christian responses to HIV and AIDS. These judgemental attitudes were not only inhumane and discriminatory but became an obstacle to seeing the pandemic as a ministry opportunity (Grubbs 2009:3). In an ubuntu professing African context, the stigma and discrimination against PLWHA showed the church as a judgemental community lacking God's compassion and lacking solidarity with the suffering. Related to this was the appearance of many faith healers who claimed to have power to heal the disease, gave suffering people false hope and made a public spectacle of desperate people.

\section{The expression of ubuntu in the work of Mashoko Christian Hospital in fighting HIV and AIDS}

Amidst the hopelessness and despair, mission hospitals such as $\mathrm{MCH}$ took up the challenge and became fountains and examples of ubuntu. This section discusses some of the ways in which the mission hospital expressed ubuntu in a difficult time.

\section{Challenged the government to accept HIV and AIDS as a human problem}

A critical element of ubuntu is a life-affirming and lifedefending character that recognises the immeasurable value of human life at all times. $\mathrm{MCH}$, like many other hospitals concerned with the problem, demonstrated the life-affirming and life-defending character of ubuntu by challenging the government to deal with HIV and AIDS as a human issue and not just an economic and political issue. According to Sibanda (2000:724), when the AIDS epidemic was first identified in the early 1980s, the Zimbabwean government did not consider it as a major public health concern because it viewed it largely as a health problem afflicting the homosexual community. The government gave it a lethargic response by not implementing solid policy measures to deal with it (Sibanda 2000:724).

Together with Kathy McCarty (1991:2), from Chidamoyo Christian Hospital, a sister medical institution located in Hurungwe district in the north-western part of Zimbabwe,
Grubbs (2009:189) reports that they first became aware of cases of HIV and AIDS among patients at the $\mathrm{MCH}$ several years before there was greater awareness of the disease in the world. He states that he was also not aware of the nature of the disease he was dealing with (Grubbs 2009:189). The serious problem, according to Grubbs (2009:192), was that when the reality of HIV and AIDS became increasingly apparent, the Government of Zimbabwe was reluctant to openly admit its existence in the country. The government feared that acknowledging the existence of HIV and AIDS in Zimbabwe would scare away tourists and jeopardise the country's economy, as tourism was a leading economic sector (Sibanda 2000:725). McCarty (1991:1-2) notes that they first noticed people living with the HIV virus in 1986 at Chidamoyo Christian Hospital and warned the government about it but were rebuffed with claims that were no confirmatory tests in the country. Grubbs (2009:198) notes the denial and delay in their response by noting that the country's first HIV / AIDS policy was not approved until 1999 when the problem was much worse (Grubbs 2009:198). The following year, the National AIDS Council (NAC) was established to oversee HIV programmes. To a large extent, then, the government's initial negative attitude and response to HIV and AIDS was part of the problem when the tragedy first surfaced.

Grubbs (2009:192) further listed frustrations such as the government's unwillingness to report the presence of HIV cases to the United Nations (UN), which gave the false impression that Zimbabwe was HIV free. He further adds that, at the time, doctors were not allowed to write 'HIV or AIDS' on patients' hospital records nor could they record it on death certificates, but at $\mathrm{MCH}$, doctors developed a way of coding HIV and/or AIDS (Grubbs 2009:192). A further frustration noted by Grubbs (2009:194) in dealing with the pandemic was the popularity of counterproductive unconventional popular beliefs such as that AIDS was an abbreviation for 'American Information to Discourage Sex' and that AIDS was developed in an American germ warfare laboratory and was spread by Central Intelligence Agency to wipe out the entire African population. In an interview on 09 June 2019, Dr Bungu corroborated Grubbs' testimony by saying that some people believed that the United States did not want the population of black people to increase and so developed AIDS in their laboratories to kill them. The perception was also acknowledged by an 84-year-old male villager from the Mashoko area, who stated in an interview on 10 June 2019 that people thought that whites hated blacks and were making them fear sex so that their population will not increase. Another elderly villager reported that many people did not believe that the disease was real until they saw many people dying. The elderly villager said that many of his brothers had died because of that kind of thinking. All the interviewed elderly people bemoaned that unfounded rumours and idle talk about HIV and AIDS led to the death of many people.

Given the swirling of the dangerous, erroneous views and the denial of the existence of the disease, $\mathrm{MCH}$ and other 
hospitals like it showed ubuntu by resolutely warning people against AIDS and calling on the government to own up for the devastating effect of the disease on people's lives. Therefore, the challenge faced by medical facilities was challenging all stakeholders to realise that, first and foremost, HIV and AIDS were real and were destroying many lives. The resilience in warning people on the dangers of lifestyle patterns, such as multiple sex partners and cultural beliefs and practices that open people to the danger of HIV infections, was a sign of ubuntu.

\section{Challenged churches to recognise the personhood of people living with HIV and AIDS}

Mashoko Christian Hospital's ministry to PLWHA expressed ubuntu by challenging churches to recognise that the affected people were full human beings created in the image of God. The churches' view of HIV and AIDS in sexual moral terms blinded them to the fact that the disease was a human problem affecting people bearing God's image, who should therefore not be discriminated against. Mhlanga (2016) insightfully points out:

HIV / AIDS stigmatization has left HIV/AIDS victims hopeless and desperate about their condition and they yearn to be loved and treated with dignity and respect as they bear the image of God. (p. 7)

One can say that the work of $\mathrm{MCH}$ as an expression of ubuntu challenged churches to uphold the human dignity of PLWHA.

Furthermore, at a time when ARV treatment medication was not yet available, $\mathrm{MCH}$ medical personnel would do their best to assist in all other ways possible. However, the incurability of HIV and AIDS made it costly and unsustainable to keep PLWHA for longer periods in hospital, coupled with rising new infections, which meant more people were in need of medical attention. Instead of just discharging PLWHA into the empty hands of poor relatives with little means, or nothing at all, to care for their bedridden relatives, the hospital demonstrated ubuntu by implementing the homebased care programme.

'Home-based care', as the phrase indicates, is effectively 'a family caring system' (Magezi \& Louw 2006:67), where care and support are provided to people within the home with their family, friends and community. Within the Churches of Christ hospitals, the concept was adopted from Chidamoyo Christian Hospital, where it was initiated in April 1991 by Sister Kathy McCarty, a senior nursing sister at the hospital (Grubbs 2009:199; McCarty 1996:55). McCarty (1996) describes the programme as set to:

$[\ldots$ D]eal with the crisis as a family problem and use the community as the primary care givers supported by the medical community instead of having institutionalized care for terminally ill patients ... Incorporated from the beginning of the project was the desire to minister holistically through medical, psychological, social and spiritual support of a person infected with AIDS and that person's family. AIDS is a disease of the family as well as of the community. (p. 54)
The programme had a team comprising the hospital chaplain, a nurse and a driver to visit homes of PLWHA discharged from the hospital. The team took with them multivitamins, medicines and equipment to the families looking after a patient. In this integrated approach, the medical nurse dealt with medical issues, while the chaplain gave spiritual support to the caregivers and the patient (Grubbs 2009:198). Each member of the team had to deal with certain dimensions of the total person (physical, spiritual and psychological).

From an ubuntu perspective, the home-based care approach affirmed the interconnectedness of life which demands that a sick person must not be compassionately cared for and not be abandoned.

Yamamori (1996:2-4) and Louw (2008:116) emphasise that the Bible demands the church to holistically minister to the whole person, not just the spiritual or the physical one. This shows that the hospital adopted a holistic approach to medical care (Bhebhe 2013 142; Mudzanire 2017:34). This act communicated God's love that affirmed the human dignity of the sick person. Furthermore, home-based care demonstrated to the families of PLWHA that the Christian hospital cared for the patients holistically. It further highlighted the understanding that the patient was not abandoned to suffer and die alone and communicated that the relatives were not left alone to watch their relative suffer and die. Home-based care signalled that discharge of PLWHA from the hospital, and even the incurability of their condition, was not a death sentence. The hospital chaplain's presence added evangelistic and pastoral care elements that resulted in the planting of churches in areas where there were no churches (Grubbs 2009:200). As already noted, planting of churches out of home-based care problems points to the problem of blurred lines between development work by FBOs and proselytising people using the same resources (Magezi 2018:6). In its defence, MCH can say that it practised the full extent of being a Christian hospital. Thus, it can be said that the scourge of the HIV pandemic challenged FBOs such as $\mathrm{MCH}$ to interrogate their understanding of what it meant to be (Christian) FBO in such a hopeless context.

The anonymously authored booklet, entitled Christian Doctrine: A Handbook for Believers published in 1992 by the Central Africa Mission Evangelistic Literature Services (CAMELS), a printing press affiliated to the Churches of Christ in Zimbabwe, gives the false impression that this church has had for long an interest in PLWHA. The booklet states (Anon 1992):

In these days of the AIDS epidemic in Zimbabwe, the church must be at the front in showing love to the victims and the families of AIDS. Some people fear ministry to AIDS sufferers because they feel that it is a judgement from God and we should not interfere with God's punishment of sinners. Others are afraid that if they touch people with AIDS, they will get the diseases themselves. When Jesus fed the four thousand (Matthew 15; 2939), he healed people for three days. The account does not mention that he preached to them. It says, 'Great crowds came to 
him, bringing the lame, the crippled, the dumb, and many others and laid them at his feet, and healed them'. Our duty is not to judge but to use whatever ministry God has given us. (p. 56)

In this extract, the church is summoned to be koinonia [fellowship and solidarity] and the diaconal [serving others] community (Acs 2:42-47; Magezi \& Louw 2006:67-71). However, tradition within the church says that the anonymously authored handbook was not written by leading figures in the male-only-led church, but by a lay American female missionary connected with $\mathrm{MCH}$ and was also not within the influential circles of the church. ${ }^{3}$ Furthermore, the handbook was written for lay people and not for the theological training of the church's ministers and leaders. If this female authorship tradition is true, then it shows that she may have written from her experience of seeing the church's judgemental and discriminatory attitude towards those affected by HIV and AIDS and therefore to challenge these negative attitudes.

\section{Empowering family units in caring for the sick}

According to Chisale (2018:1), ubuntu is 'synonymous with care ethics'. In expressing ubuntu, MCH's adoption of the home-based care programme empowered and supported families in meaningfully caring for their sick relatives who could no longer be kept in the hospitals. In many cases, PLWHA were discharged in poor and hopeless state; in essence, they were sent to die at home (Magezi \& Louw 2006:65). The complications associated with the incurability of HIV and AIDS led to strained family relations, which made it difficult to care for the afflicted person. When PLWHA were discharged to go home, there was very little support from the government and other social systems to assist both the patient and their families (Magezi \& Louw 2006:65).

In some situations, some PLWHA found themselves alone, after the death of their spouses or partners, or just abandoned by the healthier partners. In many cases, some sick people had to endure the absence of a partner working far away from home. The home-based care programme designed by the hospital supported the affected family by providing spiritual, psychological and social support.

Justifying the implementation of the home-based programme, McCarty (1996:55) said AIDS might enter a family through a single member of the family but it 'affects the physical, social and psychological, economic and spiritual well-being of all members of the family' (authors' own italics). The principle and practice of the home-based care programme affirmed the home as an effective place of caring for the sick. In traditional African cultures, there were no hospitals where patients were cared for, except in limited cases where a sick person could sojourn at the traditional healer's shrine or home. However, for the most part, healing occurred within the home and family environment. The home-based care concept invigorated this essential part of traditional African cultures.
In affirming the family home as an effective place of caring for the terminally ill, the mission hospital ultimately challenged churches to be the bigger homes that offer support to each home with PLWHA. Effectively, this called for higher levels of pastoral care and counselling. For discerning and responsive churches, the home-based care programme meant that it was no longer enough for churches to pray and do Bible study with PLWHA, but to be involved materially because in some cases food and water could be in short supply. The church as the bigger family had to not only support spiritually but in kind as well.

In essence, home-based care placed the patient in the home surrounded by family members, rather than alone at the hospital (Grubbs 2009:200). The implementation of the homebased care system affirmed the traditional African view of the home as a place of caring for sick and bedridden. In summary, in various caring and compassionate ways, $\mathrm{MCH}$, and other similar institutions, led the way in expressing ubuntu care ethics in dealing with PLWHA.

\section{The tension between faith-based organisations and churches in addressing material concerns}

This article has argued that Christian FBOs played an important role of supplementing essential deficiencies within the church's response to HIV and AIDS. Often churches define their role narrowly as preaching the gospel of salvation to 'the lost' and discipling them to be good Christians.

Other roles such as social concerns and building hospitals are often met with serious resistance from churches in fear that they would subvert the main evangelistic mission of the church (Ireland 2015). In this instance, aspects such as development, education, medical care, feeding the hungry and promoting gender justice are often seen as falling outside the main evangelistic and pastoral focus of the church. Consequently, in its ministry to PLWHA, MCH fulfilled the work shunned by the church. The hospital's provision of the home-based care programme to provide palliative care for people in advanced stages of the diseases instead of just leaving the relatives of the patients to deal with the situation on their own supplemented the care and compassion that lacked in the churches. Van Reken (1987:2) shows that medical missions or the healing ministry within the scope of the missio Dei is a demonstration of God's love and concern for the suffering people. Thus, when the church lacked ubuntu by responding in judgemental, discriminatory and stigmatising attitudes, the medical staff and chaplain at the hospital responded with embrace and support. By its compassionate responses, $\mathrm{MCH}$ demonstrated an ethic of ubuntu and complemented what lacked in the formal church.

A question may be asked that as $\mathrm{MCH}$ operated within a mission station, was it not such a part of the church that its response to HIV and AIDS could be classified as the work done by the church? After all, did not Garfield Todd, who 
initiated the establishment of the Mashoko mission centre, say concerning the hospital (Grubbs 1996):

This hospital springs from the depths of the Christian message. Jesus did and said many things when he was on earth, but some of the loveliest stories that are told of him deal with his compassion for people who were sick. Many people were brought to follow Him because of the love they saw expressed in His leading. We are so glad today that at Mashoko Mission there is added to the ministry of evangelism the ministry of healing. (p. 21)

The above quote from Todd presented the hospital as being within the mission of the church and therefore could be seen as doing the work of church. According to the South African Reformed theologian, Dirkie Smit (2004:135-144), there are at least three different forms of being 'the church': at the congregational level, at the level of denominational and ecumenical body, and at the level of individual Christians active in public life. Smit's three-dimensional view of the church depicts the different dimensions in which Christians live and exercise their faith in Christ. Therefore, in light of Smit's levels of being church, there is a sense to which the work at $\mathrm{MCH}$, and other similar Christian institutions, can be viewed as the work of the church. And indeed, statements from the leaders of the hospital indicated a self-understanding of being part of the church. Dr Bungu, the superintendent of the hospital, declares with reference to the mission of the hospital: 'We preach, teach and heal' (Bungu 2013:13). The statement signifies the quest to provide a comprehensive ministry that addresses the people's physical bodies, minds and souls (Lusby 1990:22).

However, it creates a serious distortion of the church if the church in its official capacity is not directly involved in the lives of people during their deepest suffering and they have to rely on parachurch bodies to keep their body and soul together. Haddad (2005: 33) highlights the cries of two women who mourned the absence of the formal church in their affliction by HIV and AIDS. One woman stated (Haddad 2005):

Church groups always come when we are dying or even already gone. But when we are trying to live with HIV, when we really need them most, Christians are nowhere to be seen. (p. 33)

The other woman declared, 'I would rather come to Bible study than go to church' (Haddad 2005:33). The gist of these complaints is the exclusion from the church in its official capacity. Furthermore, while the Bible study groups are indeed part of the church, they exist on the fringes as neglected parts of the body. This gives the impression that the formal church is only concerned with the soul of the person and not the body. When the pastor of the church only shows up to bury the dead, and is not involved in daily material struggles, it shows a great prioritisation of the soul over the body. Chirongoma (2006) says:

Most Christians rely on their congregations as a support system. If their congregations fail to assist them at their time of greatest need, they often have nowhere else to turn. (p. 184)

\section{The challenge of faith-based organisations to the church in epidemical situations}

This closing section highlights the lessons that must be learnt by churches from FBOs in dealing with the HIV and AIDS issues and other epidemical situations. These lessons are also applicable to other areas of life that call for the involvement of the church in suffering and poverty.

\section{Recognition of the inhumanness of the HIV and AIDS stigma}

A critical lesson from FBOs involved in the fight against HIV and AIDS, such as $\mathrm{MCH}$, is that churches ought to learn to recognise the inhumanness of stigmatisation. Mashoko Christian Hospital challenged the church in the context of HIV and AIDS to practise ubuntu by not stigmatising PLWHA. Instead, the church must be a community of care and compassion.

The need for the church to not stigmatise but exercise care and compassion is emphasised by Smit (2003) in the following words:

Could it perhaps be that suffering, especially in radical poverty, challenges the Christian church to see in such a fundamental way that the very being of the church is itself at stake? Could it possibly be that, if we fail to see this - to perceive, to accept, and to understand - we fail to remain church? Could it indeed be true that what we do will depend on what we see, what we see will depend on who we are, and what we fail to see will impact on our integrity itself? (pp. 57-58)

If failing to see suffering and meaningfully respond to it has such a serious effect on the integrity of the church, then to see the suffering and pain of others and mock is rejection of the gospel of Christ - who was moved by the pain of the people and 'went about all cities and villages, teaching in their synagogues and preaching the gospel of the kingdom, and healing every sickness and every disease among the people' (Mt 9:3). Instead of stigmatisation, churches should follow Jesus's pattern in conveying the gospel holistically (Mudzanire 2017:26).

\section{A comprehensive theology of HIV and AIDS that affirms the uniqueness of the church}

Even though the medical missions of the church have been involved in fighting HIV and AIDS since the early days following the discovery of the HIV virus and disease in the country, there remains no clear official theology or policy dealing with this problem among the Churches of Christ in Zimbabwe. This is unfortunate in light of the fact that the hospitals of the church first interacted with the first cases of HIV and AIDS in 1986 (McCarty 1991:2). While various congregations and individuals run children's homes that target HIV and AIDS orphans, there remain no systematic and collaborative efforts within the family of Churches of Christ in dealing with this from a unique Christian pastoral 
care perspective. Schenk (1993:68) challenges churches to define their position on people living with HIV and those directly and indirectly affected by it. This is a call for the need for churches to develop a meaningful theological framework of engaging issues including life-threatening realities, such as HIV and AIDS. In other words, there is a need for Churches of Christ in Zimbabwe to critically reflect on their basic understanding of what it means to be the church in a context of HIV and AIDS (Magezi \& Louw 2006:66). There is no doubt that in order for the believers within these churches to serve each other, there is a need for a well-developed theology of diaconia [service] and kononia [fellowship and solidarity] that will empower lay people to effectively practise informed compassionate care at the grassroots level (Magezi \& Louw 2006:67).

However, a Christian response to HIV and AIDS that promotes ubuntu must be comprehensive and should not compromise the uniqueness of the church. It is noted that the harmful and inhuman judgemental responses to HIV and AIDS come from ignorance about the disease. Some harmful positions were prompted by the desire to uphold and preserve the holiness of sex. The resistance of churches towards promoting HIV interventions that went beyond abstinence and faithfulness in marriage, such as condom distribution to adolescents and unmarried youths, stemmed from a deep commitment to uphold the holiness and purity of sexual activity.

However, the evident reality of many adolescents and unmarried youths is that many of them do not abstain from sexual activities until marriage. Therefore, in order to avoid new infections and the spread of the virus, churches need to formulate a comprehensive theological response to the problem of HIV and AIDS that seriously takes into account the realities on the ground, the uniqueness of the church and God's demand for moral purity. A serious problem that constantly hinders effective strategies of combating HIV is that churches often provide simplistic solutions to complex human problems. Simultaneously, critics of the church often fail or simply ignore the church's commitment to God's demand for sexual moral purity. A comprehensive response entails collaboration with all the stakeholders concerned with eradicating the HIV virus. The problem is that in many cases, pastors and prophets often subvert the biblical priesthood of all believers by claiming monopoly of all knowledge about important issues affecting daily life. It is this monopolisation of all knowledge that leads to demonising condoms and ARVs. However, at all times, the church is called to develop comprehensive, useful strategies that promote abundant life (Jn 10:10) but still uphold the uniqueness of the church without which it ceases to be Christ's holy church. A key in this is developing an appropriate method of reading and interpreting the Bible that meaningfully addresses reproductive health issues, sexual purity for all people - the adolescent, the youth, the married, the single and the widowed - healing and the use of medicines such as ARVs and a host of other issues involved. A simplistic theological solution will disempower people from meaningfully engaging with the HIV and AIDS pandemic.

\section{Recognition of the gendered nature of HIV and AIDS}

HIV and AIDS, particularly in Africa, have a gendered nature by having a heavier toll on women and also thriving on the powerlessness of women. The fact that HIV and AIDS are gendered points out that women bear the brunt of this epidemic because of various aspects of powerlessness that leave them unable to negotiate for safe sex. As already noted in the above discussion, ever since the discovery of HIV and AIDS in Africa, the people who were affected the most were women and subsequently children. In patriarchal societies, which is common in most of Africa, the gendered nature of HIV thrives on women's lack of economic and social power, which takes away their decision-making power, leaving them (Dube 2008):

$[D]$ ependent upon their partners, be their husbands, lovers, brothers, uncles or fathers, and hence are unable to insist on safer sex for they have no control over their bodies, nor are they able to fend for themselves. (p. 103)

The point is that women's sexuality is dominated by men creating a powerlessness that exposes them to risks of HIV and AIDS. As Dube (2008) further points out:

The lack of power for most women in heterosexual relations, [sic] means that they have little or no control over their own bodies. The question whether they can/should have protected or unprotected sex, whether they want children or not, whether they should breast feed or not breast feed in case of an infected mother, whether they should disclose their HIV\&AIDS status [or] not, or whether they have the right to know the status of their partners or not are choices not easily available to most women. These factors which make women vulnerable to infection, unlikely to live a long qualitative life if infected and likely to be hit hard by the impact of HIV \& AIDS. (p. 103)

Dube draws attention to the urgent need to empower women to play a leading role in fighting HIV and AIDS. The church is therefore called to recognise the gendered nature of HIV and AIDS and challenge ubuntu practices that promote the powerlessness of women, leaving them vulnerable to the disease.

Chitando's call for the depatriachalisation of ubuntu has already been noted. However, gender issues are hotly debated in the patriarchy oriented Zimbabwean Churches of Christ where the central ministry of the church is in the hands of men who incidentally are a minority group in the church. Gender issues in the Churches of Christ across the world are worsened by the tradition of Biblicism and Literalism where texts such as 1 Corinthians 13:34 that states that women should remain silent in the churches and 1 Timothy 2:11-12 that states women should learn in quietness and full submission are interpreted literally and simplistically with very little regard to both how other texts portray women and 
the general contextual complexities surrounding the issue. Unfortunately, Alexander Campbell, one of the key founders of the movement of Churches of Christ (known as the Restoration Movement), gave conflicting views on the status of women but generally seemed to concur with the Reformers Martin Luther and John Calvin that 'God designed woman as the helper of man and that her divinely appointed role is secondary, supportive and subordinate' (Massey 2016:2). In Zimbabwe, the marginalisation of women in the church is further exacerbated by patriarchal African traditional culture where women are considered subordinate to men.

Machingura (2012:316) highlights the fact that in Zimbabwe not only is the vulnerability of women worsened by the denial of the right and power to negotiate for safe sex even in risky marriages and relationships, it is further exacerbated by the projection of HIV and AIDS as a women's disease. One finds such deregulatory Shona references to HIV and AIDS as chigwere chavakadzi and Ndebele statements like isifo sabafazi, meaning HIV and AIDS are women's diseases. Machingura (2012) concludes, therefore, that the:

[G]eneral perspective is that women symbolically are the sources of the virus, an understanding that really needs a lot of cooperation from all sectors if this negative attitude is going to be successively corrected. (p. 316)

To address this, it is necessary to reconstruct gender perceptions, to ensure gender justice by reforming the theologies, polices and praxis of the churches. Essentially, the patriarchally oriented churches need to take seriously the plight of women and be proactively engaged in addressing it by promoting not only gender equality but also the full authentic humanness and the human integrity of femininity. There is a need to realise the fact that women are not an accident in God's order of creation or an afterthought, but that God created them intentionally and in his full image. This requires a gender-sensitive reading and interpretation of the Bible.

\section{Conclusion}

This article sought to answer the question: From a perspective of the African philosophy of ubuntu, how did the ministry of the Christian FBOs to PLWHA challenge the fear and judgemental attitudes towards the affected people? The article highlighted that by and large churches did not demonstrate ubuntu compassion and care towards PLWHA. The article pointed out that Christian FBOs such as $\mathrm{MCH}$ played a considerable role in fulfilling what the formal churches failed to provide to PLWHA. Therefore, the Christian FBOs must be applauded for complementing the compassion and care that is often lacking in the churches' response to problems such as HIV and AIDS. Ubuntu care ethics challenges the churches in Africa to take seriously the fact that many poor people depend on the church for their material welfare in times of crises. This essentially calls for churches to be alert to the problems surrounding them and think of new effective ways for addressing them. There is a need for churches to support and embrace FBOs because they often supplement what is lacking in the churches.

\section{Acknowledgements Competing interests}

The authors have declared that no competing interests exist.

\section{Authors' contributions}

C.B. and S.M. equally contributed to the research and the writing of this article.

\section{Ethical consideration}

This article followed all ethical standards for carrying out research without direct contact with human or animal subjects.

\section{Funding information}

This research received no specific grant from any funding agency in the public, commercial or not-for-profit sectors.

\section{Data availability statement}

Data sharing is not applicable to this article as no new data were created or analysed in this study.

\section{Disclaimer}

The views and opinions expressed in this article are those of the authors and do not necessarily reflect the official policy or position of any affiliated agency of the authors.

\section{References}

Anon., 1992, Christian doctrine: A handbook for believers, Central Africa Mission Evangelistic Literature Services, Masvingo.

Bhebhe, M., 2013, An African culture of multiple religiosity: The perspective of the Church of Christ in Zimbabwe, Lambert Academic, Saarbrucken.

Bosch, D.J., 2011, Transforming mission: Paradigm shifts in theology of mission, Orbis Books, New York.

Bungu, Z.J.T., 2013, Mashoko medical evangelism, Asheis USA 2013 Report, Mashoko Christian Hospital, Mashoko.

Chirongoma, S., 2006, 'Women, poverty, and HIV in Zimbabwe: An exploration of inequalities in health care', in I.A. Phiri \& S. Nadar (eds.), African women, religion, and health: Essays in honour of Mercy Amba Ewudziwa Oduyoye, pp. 173-186, Orbis Books, Maryknoll, NY.

Chisale, S.S., 2018, 'Ubuntu as care: Deconstructing the gendered Ubuntu', Verbum et Ecclesia 39(1), a1790. https://doi.org/10.4102/ve.v39i1.1790

Chitando, E., 2015, "Do not tell the person carrying that s/he stinks": Reflections in Ubuntu and masculinities in the context of sexual and gender-based violence and HIV', in E. Mouton, G. Kapuma, L. Hansen \& T. Togom (eds.), Living with dignity: African perspectives on gender equality, pp. 269-284, Sun Press, Stellenbosch.

Dube, M.W., 2008, The HIV \& AIDS Bible: Selected essays, University of Scranton, Chicago, IL.

Gade, C.B.N., 2011, 'The historical development of the written discourses on ubuntu', South African Journal of Philosophy 30(3), 303-329. https://doi.org/10.4314/ sajpem.v30i3.69578

Gathogo, J.M., 2007, 'Revisiting African hospitality in post-colonial Africa', Missionalia 35(2), 108-130.

Grubbs, D., 1996, 'Mashoko Christian Hospital', Central Africa Story 30(20), 20-21.

Grubbs, D.A., 2009, The Partridge principle: A memoir of life in Zimbabwe, Cincinnati Christian University, Cincinnati, $\mathrm{OH}$.

Haddad, B., 2005, 'Reflections on the church and HIV/AIDS: South Africa', Theology Today 62(1), 29-37. https://doi.org/10.1177/004057360506200104 
Hoffman, M.A., 1996, Counselling clients with HIV disease: Assessment, intervention, and prevention, Guilford Press, New York.

Ireland, J.M., 2015, Evangelism and social concern in the theology of Carl F. H. Henry, Wipf and Stock Publishers, Eugene, OR.

Kelly, A., 2009, 'The body of Christ has AIDS: The Catholic Church responding faithfully to HIV and AIDS in Papua New Guinea', Journal of Religion and Health 48(1), 16-28. https://doi.org/10.1007/s10943-008-9220-z

Letseka, M., 2012, 'In defence of ubuntu', Studies in Philosophy and Education 31(1), 47-60. https://doi.org/10.1007/s11217-011-9267-2

Letseka, M., 2013, 'Anchoring ubuntu morality', Mediterranean Journal of Socia Sciences 4(3), 351-360. https://www.mcser.org/journal/index.php/mjss/article/ view/483.

Louw, D.J., 2008, Cura Vitae: Illness and the healing of life in pastoral care and counselling, Lux Verbi, Wellington.

Lusby, L., 1990, Historical survey of the Central Africa Mission Zimbabwe, Kentucky Christian College, Grayson, GA.

Machingura, F., 2012, 'The Pentecostal churches' attitude towards people living with HIV and AIDS in in Zimbabwe: Exclusion or inclusion?', in J. Pock, B. Hoyer \& $\mathrm{M}$. Schüßler (eds.), Ausgesetzt: Exklusionsdynamiken und Exposureprozesse in der M. Schüßler (eds.), Ausgesetzt: Exklusionsdynamiken und
Praktischen Theologie, pp.305-319, LIT Verlag, Münster.

Magezi, V. \& Louw, D.J., 2006, 'Congregational home-based pastoral care: Merging the African family and church family systems for effective HIV ministry', Journal of Theology for Southern Africa 125 (July), 64-79.

Magezi, V., 2012, 'From periphery to the centre: Towards repositioning churches for meaningful contribution to public health care', HTS Teologiese Studies/Theological Studies 68(2), Art. \#1312, 8 pages. https://doi.org/10.4102/hts.v68i2.1312

Magezi, V., 2017, 'Ubuntu in flames - Injustice and disillusionment in post-colonia Africa: A practical theology for new "liminal ubuntu" and personhood", in J. Dreyer, Y. Dreyer, E. Foley \& M. Nel (eds.), Practicing ubuntu: Practical theological perspectives on injustice, personhood and human dignity, pp. 111-122, LIT Verlag, Zurich.

Magezi, V., 2018, 'Church-driven primary health care: Models for an integrated church and community primary health care in Africa (a case study of the Salvation Army in East Africa)', HTS Teologiese Studies/Theological Studies 74(2), 4365. https:// doi.org/ 10.4102/hts.v74i2.4365

Manyonganise, M., 2015, 'Oppressive and liberative: A Zimbabwean woman's reflections on ubuntu', Verbum et Ecclesia 36(2), Art. \#1438, 1-7. https://doi. org/10.4102/ve.v36i2.1438

Marshall, M. \& Taylor, N., 2006, 'Tackling HIV and AIDS with faith-based communities: Learning from attitudes on gender relations and sexual rights within loca evangelical churches in Burkina Faso, Zimbabwe, and South Africa', Gender \& Development 14(3), 363-374. https://doi.org/10.1080/13552070600980344

Masango, M., 2006, 'African spirituality that shapes the concept of Ubuntu', Verbum et Ecclesia 27(3), 930a-943. https://doi.org/10.4102/ve.v27i3.195

Massey, L.F., 2016, 'Alexander Campbell and the status of women: A case study in ambivalence', Priscilla Papers 30(4), 16-21.

Mbiti, J.S., 1990, African religions \& philosophy, 2nd edn., Heinemann Educational Botswana, Gaborone.

Mbona, M., 2013, 'Mission in turbulent waters: AIDS-related care and mitigation by the Roman Catholic Church in Manicaland, Zimbabwe (1985-2007)', Studia Historiae Ecclesiasticae 39(1), 1-16.

Mboti, N., 2015, 'May the real ubuntu please stand up?', Journal of Media Ethics 30(2) 125-147. https://doi.org/10.1080/23736992.2015.1020380
McCarty, K., 1996, 'Home care for AIDS patients in Zimbabwe', in T. Yamamori, B.L. Myers, K. Bediako \& L. Reed (eds.), Serving with the poor in Africa, pp. 33-46, MARC, Monrovia, CA

McCarty, K., 1991, 'Jesus: The hope', Central Africa Story 33(Annual), 24.

Meiring, J.J.S., 2015, 'Ubuntu and the body: A perspective from theological anthropology as embodied sensing', Verbum et Ecclesia 36(2), Art. \#1423, 8 pages. https://doi.org/10.4102/ve.v36i2.1423

Mhlanga, S.S., 2016, 'Christian response to HIV/AIDS: A teaching series for the church in Zimbabwe', Doctoral thesis, Southern Baptist Theological Seminary, Louisville, KY.

Morgan, R., Green, A. \& Boesten, J., 2014, 'Aligning faith-based and national HIV/AIDS prevention responses? Factors influencing the HIV/AIDS prevention policy process and response of faith-based NGOs in Tanzania', Health Policy and Planning 29(3), 313-322. https://doi.org/10.1093/heapol/czt018

Mudzanire, S., 2017, 'A historical-missiological account of the work of the Church of Christ at Mashoko Mission with a focus on its vision and strategy', A Post-Graduate Diploma thesis, Stellenbosch University, Stellenbosch.

Oduyoye, M.A., 1997, 'The future of the church in Africa: its mission and theology', in J.N. Mugambi (ed.), The church and reconstruction of Africa: theological considerations, pp. 66-83, AACC, Nairobi.

Pallant, D., 2012, Keeping faith in faith-based organizations: A practical theology of Salvation Army health ministry, Wipf and Stock Publishers, Eugene, OR.

Schenk, E.A., 1993, 'Care of the person with HIV/AIDS: The biblical mandate', Ashland Theological Journal 25, 68-74.

Sibanda, A., 2000, 'A nation in pain: Why the HIV/Aids epidemic is out of control in Zimbabwe', International Journal of Health Services 30(4), 717-738. https://doi. org/10.2190/4M70-6CX9-HPU9-9LT4

Sider, R.J. \& Unruh, H.R., 2004, 'Typology of religious characteristics of social service and educational organizations and programs', Nonprofit and Voluntary Sector Quarterly 33(1), 109-134. https://doi.org/10.1177/0899764003257494

Smit, D.J., 2003, 'On learning to see? A reformed perspective on the church and the poor', in P.D. Couture \& B.J. Miller-McLemore (eds.), Poverty, suffering and HIV AIDS: International practical theological perspectives, pp. 55-70, Cardiff Academy, Cardiff.

Smit, D., 2004, 'The impact of the church in South Africa after the collapse of the Apartheid regime', in K. Bediako, M. Jansen, J. Van Butselaar \& A. Verburg (eds.), A new day dawning: African Christians living the gospel: Essays in honour of Dr J.J. (Hans) Visser, pp. 128-149, Uitgeverij Boekencentrum, Zoetermeer.

Togarasei, L., 2010, 'Christian theology of life, death and healing in an era of antiretroviral therapy: Reflections on the responses of some Botswana churches' African Journal of AIDS Research 9(4), 429-435. https://doi.org/10.2989/160859 06.2010 .545658

Tutu, D., 2009, No future without forgiveness, Random House, New York.

Van der Merwe, W., Swart, I. \& Hendriks, J., 2009, 'Faith-based organisations in the context of social welfare and development in South Africa: Towards a conceptualisation', Social Work/Maatskaplike Werk 45(2), 123-139. https://doi. org/10.15270/45-2-210

Van Norren, D.E., 2014, 'The nexus between Ubuntu and global public goods: Its relevance for the post 2015 development agenda', Development Studies Research An Open Access Journal 1(1), 255-266. https://doi.org/10.1080/21665095.2014. 929974

Van Reken, D.E., 1987, Mission and ministry: Christian medical practices in today's changing world cultures, Billy Graham Centre, Wheaton, IL.

Yamamori, T., 1996, Serving with the poor in Africa, MARC, Monrovia, CA. 